\title{
GENDER MAINSTREAMING DALAM KEBIJAKAN PENDIDIKAN ISLAM TAHUN 2010-2014
}

\author{
Ainur Rofi'ah \\ Universitas Islam Negeri Sunan Ampel Surabaya, Indonesia \\ E-mail: aal.udin0@gmail.com
}

\begin{abstract}
This article examines the gender mainstreaming in Islamic education policy for 2010-2014 adopted by the Ministry of Religious Affairs of the Republic of Indonesia. Using a qualitative descriptive approach, this article explores the extent of the strategic plan of the Ministry of Religious Affairs in 2010-2014, especially policies that are gender neutral and gender responsive policies. The author underlines that the government needs to undertake the planning policies or programs that are more responsive to gender. One of the strategies adopted to fulfill the practical and strategic needs in this context is through Gender Mainstreaming which is implemented in relevant and significant programs. The author also asserts that Gender Mainstreaming in Islamic education is very necessary. Norms that have been frequently used as a reference for the gender policy should be reconsidered. This is to ensure that policies are drawn right on target, though — all parties must realize that-the uniform policy cannot necessarily be applied because of gender roles, however, differ both between places, time and socio-economic class.
\end{abstract}

Keywords: Gender Mainstreaming; Islamic Education Policy.

\section{Pendahuluan}

Menyukseskan pembangunan diperlukan sumber daya manusia yang berkualitas tinggi. Untuk menciptakan sumber daya manusia yang berkualitas tinggi, diperlukan pendidikan yang berkualitas baik pula. Mengikutsertakan laki-laki dan perempuan dalam pembangunan berarti memanfaatkan sumber daya manusia yang potensial dan, seharusnya, merupakan tindakan yang efisien dan efektif. Apalagi jika hal ini didukung oleh kualitas sumber daya manusia yang berlatarbelakang pendidikan baik dan excellent. Dengan demikian, 
sumber daya manusia yang berkualitas tinggi merupakan keniscayaan dalam pembangunan dan, sebagai mafhûm mukhâlafah-nya, sumber daya manusia yang berkualitas rendah hanya akan menjadi beban bagi pembangunan.

Dalam konteks ini, pendidikan mempunyai arti yang sangat penting. Undang-Undang Dasar (UUD) 1945 mengamanatkan bahwa laki-laki dan perempuan memiliki hak dan kewajiban yang sama dalam pembangunan, termasuk pembangunan di bidang pendidikan. Namun masih ditemukan fakta di lapangan (tataran implementasi) yang menunjukkan bahwa banyak perempuan mengalami ketertinggalan daripada laki-laki dalam berbagai bidang pembangunan, baik sebagai pelaku maupun sebagai penikmat hasil pembangunan, termasuk pembangunan di bidang pendidikan. Artinya, masih terdapat ketimpangan gender (gender inequality) di bidang pendidikan. ${ }^{1}$

Pada pasal 5 ayat 1 Undang-Undang Nomor 20 Tahun 2003 tentang Sistem Pendidikan Nasional dinyatakan bahwa setiap warga negara, baik laki-laki maupun perempuan, mempunyai hak yang sama untuk memperoleh pendidikan yang bermutu. Kesempatan memperoleh pendidikan tersebut tidak dibedakan menurut jenis kelamin, status sosial ekonomi, agama dan lokasi geografis. Kebijakan pemerataan dan perluasan kesempatan dalam pendidikan ini menekankan bahwa setiap orang tanpa memandang asal-usulnya mempunyai akses yang sama terhadap pendidikan pada semua jenis, jenjang, maupun jalur pendidikan sehingga diharapkan bahwa keadilan di dalam pelayanan pendidikan akan meningkat. Dasar pemerataan pendidikan bukan semata-mata pemerataan hanya untuk pemerataan tetapi pemerataan pendidikan untuk mencapai keadilan dan kesejahteraan yang merata.

Wacana tentang kesetaraan laki-laki dan perempuan lazim disebut sebagai kesetaraan gender (gender equality). Dalam memahami konsep gender, Mansour Fakih membedakannya antara gender dan seks (jenis kelamin). Pengertian seks lebih condong pada penyifatan atau pembagian dua jenis kelamin manusia berdasarkan ciri biologis yang melekat, tidak berubah dan tidak dapat dipertukarkan. Dalam hal ini sering dikatakan sebagai ketentuan Tuhan atau kodrat. Sedangkan konsep gender adalah sifat yang melekat pada laki-laki atau perempuan yang dikonstruksi secara sosial maupun kultural dan dapat

${ }^{1}$ Gadis Arivia, Feminisme: Sebuah Kata Hati (Jakarta: Penerbit Buku Kompas, 2006), 408. 
dipertukarkan. Artinya, semua hal yang dapat dipertukarkan antara sifat laki-laki dan perempuan, yang bisa berubah dari waktu ke waktu, dari tempat ke tempat lainnya, maupun berbeda dari suatu kelas ke kelas yang lain disebut dengan "gender".

Istilah gender sendiri diketengahkan oleh para ilmuwan sosial untuk menjelaskan perbedaan perempuan dan laki-laki yang bersifat bawaan sebagai ciptaan Allah dan yang merupakan bentukan budaya yang dikonstruksikan, dipelajari, dan disosialisasikan. Pembedaan ini sangat penting karena selama ini seringkali dicampuradukan ciri manusia yang kodrati dan tidak dapat berubah atau diubah, dengan ciri manusia yang bersifat non-kodrati yang sebenarnya dapat berubah atau diubah. Dengan kata lain, masyarakat tidak membedakan yang mana sebetulnya jenis kelamin (kodrat) dan yang mana gender (nonkodrati). ${ }^{3}$

Wacana dan gerakan gender berangkat dari realitas ketertindasan, dan keterpinggiran (marginalisasi) kaum perempuan dalam banyak ranah kehidupan, termasuk di dalamnya yang sangat penting adalah ranah pendidikan. Padahal, sebagaimana dinyatakan oleh Ramayulis, pendidikan perempuan dalam ajaran Islam termasuk kewajiban agama karena pengetahuan merupakan suatu kebutuhan asasi bagi manusia. Pendidikan bagi perempuan tidak terbatas pada pendidikan agama saja tetapi meliputi juga pendidikan rumah tangga, misalnya cara mendidik dan membesarkan anak, pendidikan sosial kemasyarakatan dan pendidikan intelektual.

Dalam Konvensi Antidiskriminasi terhadap Perempuan (Convention on the Elimination of All Forms of Discrimination Against Women/CEDAW) perihal kesetaraan dalam pendidikan, pada pasal 10, ditetapkan bahwa negara-negara peserta, termasuk Indonesia, wajib untuk mengambil semua upaya yang tepat untuk menghapus diskriminasi terhadap perempuan dalam rangka memastikan hak yang sama dengan laki-laki di bidang pendidikan dan terutama untuk menjamin penghapusan setiap konsep stereotip tentang peranan lakilaki dan perempuan di semua tingkat dan semua bentuk pendidikan. ${ }^{4}$ Munculnya berbagai fenomena disparitas dalam pendidikan sekolah memperlihatkan belum adanya kemampuan pihak-pihak berwenang-

\footnotetext{
2 Mansour Fakih, Analisis Gender dan Transformasi Sosial (Yogyakarta: Pustaka Pelajar, 2004), 39.

3 Ibid., 109.

${ }^{4}$ Handayani, Konsep dan Teknik Penelitian Gender (Malang: UMM Press, 2002), 36.
} 
terkait dalam menghapuskan gender stereotype, misalnya dalam hal materi pendidikan sekolah terutama di tingkat dasar, yang masih memperlihatkan ketidakadilan gender.

Meskipun kebijakan nasional di bidang pendidikan sudah cukup memadai untuk dijadikan acuan pembangunan pendidikan yang berwawasan gender, namun dalam realitasnya masih saja terjadi ketimpangan gender (gender disparity). Sejumlah hasil penelitian mengungkapkan bahwa kesenjangan gender bukan diakibatkan oleh satu faktor tunggal, melainkan terdapat sejumlah faktor yang saling terkait-berkelindan. Setidaknya, dalam tulisan, dapat disebutkan empat faktor utama, yakni faktor akses, kontrol, partisipasi dan benefit. Faktor akses terlihat nyata, terutama, dalam proses penyusunan kurikulum dan proses pembelajaran yang cenderung bias laki-laki (male-bias).

Masih ditemukan juga fakta di lapangan yang menunjukkan bahwa tidak semua warga negara bisa mengakses pendidikan yang layak. Masalah gender bias di kalangan masyarakat ternyata menjadi salah satu penyebab beberapa anak bangsa tidak mendapatkan hak pendidikan. Padahal ajaran Islam menyebutkan bahwa tidak ada perlakuan diskriminatif bagi setiap individu baik laki-laki maupun perempuan di muka bumi ini yang didasarkan pada perbedaan jenis kelamin, status sosial, ataupun ras. Semua manusia memiliki kedudukan yang sama di sisi Allah. Allah membedakan kedudukan manusia di sisi-Nya hanya berdasarkan kualitas ketakwaan mereka. ${ }^{5}$

Salah satu strategi kebijakan yang ditempuh untuk memenuhi kebutuhan praktis dan strategis bagi perempuan adalah Program Pengarusutamaan Gender (PUG) atau Gender Mainstreaming. PUG telah menjadi pilar strategis dalam pembangunan nasional untuk mencapai kesetaraan gender. Sebagai lembaga yang mengayomi penyelenggaraan pendidikan agama Islam, madrasah, dan pondok pesantren, Kementerian Agama (Kemenag), misalnya, telah berupaya menjalin kemitraan dengan lembaga internasional untuk peningkatan kualitas dan pengembangan madrasah yang antara lain PUG dalam pendidikan Islam. Pengarusutamaan gender menjadi penting dalam berbagai aspek pembangunan. Kesenjangan gender di bidang pendidikan terjadi di mana posisi perempuan kurang menentukan

5 Tim Penyusun, Membangun Relasi Setara antara Perempuan dan Laki-laki melalui Pendidikan Islam (Jakarta: Direktorat Jenderal Pendidikan Kementerian AgamaAustralia Indonesia Partnership, 2010), 33-34. 
dalam mempengaruhi arah dan jalannya pendidikan. Hal ini mengakibatkan terjadinya kesenjangan gender yang terlegitimasikan dalam berbagai dimensi sistem pendidikan, termasuk pendidikan Islam.

Meskipun demikian, belum ada akuntabilitas dan jaminan keberlanjutan program oleh Kemenag sendiri sehingga harus diakui secara objektif bahwa kesenjangan gender masih (mungkin) terjadi di lembaga ini. Pemikiran di atas setidaknya dilandasi oleh beberapa fakta, antara lain: pertama, data EMIS tentang angka partisipasi sekolah siswi lebih rendah daripada siswa; kedua, semakin tinggi jenjang pendidikan, semakin kecil jumlah partisipasi perempuan; ketiga, jumlah guru perempuan dan laki-laki di madrasah ibtida'iyah sebenarnya seimbang, tetapi dalam pengajuan sertifikasi guru ternyata guru lakilaki lebih banyak lulus dibandingkan guru perempuan karena partisipasi guru perempuan lebih rendah dibandingkan guru laki-laki, baik dalam bidang karya tulis ilmiah maupun peningkatan jenjang karier; keempat, sejumlah buku atau lembar kerja siswa atau siswi masih memuat bias gender sebagai akibat pemahaman Islam secara tekstual yang terdapat dalam referensi guru sehingga berimplikasi pada pengembangan bahan ajar; dan kelima, beberapa guru dan kepala madrasah masih banyak yang belum memiliki sensitivitas gender (gender sensitivity). ${ }^{6}$

Uraian di atas menyiratkan bahwa implementasi kebijakan PUG dalam pendidikan Islam masih perlu dipertanyakan kembali. Kesetaraan gender sangat penting diperjuangkan demi terciptanya keadilan, kesejahteraan, dan keharmonisan laki-laki dan perempuan dalam kehidupan. Diperlukan usaha penyadaran, dengan demikian, terhadap anggota masyarakat yang terikat oleh suatu struktur yang secara hegemonik bias gender. Meskipun harus diakui bahwa usaha penyadaran dimaksud memerlukan tenaga, waktu dan mungkin biaya yang tidak sedikit. Hal ini karena proses pembentukan hegemoni ini berlangsung melalui proses interaksi, negosiasi dan pengambilan keputusan atau kebijakan yang pada akhirnya menempatkan posisi perempuan dalam struktur hubungan yang timpang, ${ }^{7}$ sehingga berbagai produk kebijakan, program dan kegiatan serta wacana yang

6 Mufidah Ch., "Hasil Evaluasi Implementasi PUG Bidang Pendidikan Islam," Monev Pilot Project Pengarusutamaan Gender Bidang Pendidikan Islam di Yogyakarta, 5-6 Maret 2010 (Dokumen Tidak Dipublikasikan--Program Kemitraan Kementerian Agama dengan MCPM-AIBEP).

${ }^{7}$ Fakih, Analisis Gender, 123. 
berkembang di seputar masalah pendidikan diwarnai oleh struktur hegemonik tersebut, yang cenderung timpang dan bias gender.

Data Badan Pusat Statistik (BPS), misalnya, menunjukkan ratarata angka masuk perempuan ke lembaga pendidikan lebih kecil jika dibandingkan dengan angka masuk laki-laki. Semakin tinggi jenjang pendidikan, semakin kecil angka rata-rata masuk perempuan. ${ }^{8}$ Ada tiga hal yang, menurut hemat penulis, dapat dijadikan analisis bagi teriadinya kesenjangan pendidikan ini. Pertama adalah persepsi masyarakat tentang anak perempuan. Dibandingkan dengan anak lakilaki, anak perempuan tidak diuntungkan secara kultur. Pada umumnya, masyarakat beranggapan bahwa laki-laki adalah penompang ekonomi keluarga, untuk itu pendidikan bagi anak lakilaki merupakan suatu keharusan untuk dicapai, karena dengan semakin tinggi pendidikan anak laki-laki diharapkan mendapatkan pekerjaan yang sesuai dengan pendidikannya. Anak laki-laki oleh sebagian besar masyarakat masih dianggap sebagai sarana mencari nafkah. Sementara itu nilai-nilai yang diberlakukan pada anak perempuan didasarkan pada anggapan bahwa perempuan yang baik adalah perempuan yang bisa menjadi ibu rumah tangga yang baik. Dalam konteks ini, masyarakat kurang memberi toleransi kepada anak perempuan untuk mengenyam pendidikan lebih tinggi, karena pada akhirnya anak perempuan harus kembali ke rumah dan menjadi ibu rumah tangga.

Kedua adalah orientasi pendidikan yang tidak melihat aspek perbedaan gender sebagai variable utama kebijakan. Kebijakan pendidikan lebih ditujukan kepada masyarakat secara umum tanpa membeda-bedakan jenis kelamin. Orientasi pendidikan semacam itu boleh saja, namun orientasi itu mengesampingkan kaum perempuan yang secara kultur belum cukup baik untuk mengenal sekolah dalam kehidupannya. Dalam konteks ini, perempuan yang secara kultur tidak diberi ruang, maka secara struktur dan kebijakan negara tidak dapat mendorong secara khusus anak perempuan untuk melakukan aktivitas bersekolah. Ketiga adalah akses pendidikan yang dikeluarkan oleh pemerintah kurang menjangkau masyarakat yang berada di pedalaman. Dalam situasi yang serba kekurangan dan secara akses juga sulit, maka pilihan bagi sejumlah keluarga tertuju pada pilihan untuk membuat anak perempuannya bekerja dibandingkan harus

8 Zaitunah Subhan, Menggagas Pemberdayaan Fiqh Perempuan (Jakarta: El-Kahfi, 2008), 400. 
bersekolah yang justru memerlukan biaya yang berarti akan semakin memberatkan ekonomi rumah tangga.

\section{Gender dalam Islam}

Dalam al-Qur'ân memang tidak ditemukan kata yang persis dengan istilah gender. Akan tetapi jika yang dimaksud adalah menyangkut perbedaan laki-laki dan perempuan secara biologis, yaitu meliputi perbedaan fungsi, peran dan relasi antara keduanya, maka dapat ditemukan sejumlah istilah untuk itu. Semua istilah yang digunakan oleh al-Qur'ân bagi laki-laki dan perempuan dapat dijadikan obyek penelusuran, seperti istilah al-rajul, al-rijal, al-mar'ah, alnisâ', al-dhakar dan al-unthâ. Hal ini termasuk gelar status untuk lakilaki dan perempuan, seperti suami (al-zawy) dan istri (al-zawjab), ayah (al-ab) dan ibu (al-umm), saudara laki-laki (al-akb) dan saudara perempuan (al-ukht), kakek (al-jadd) dan nenek (al-jaddab), orang Islam laki-laki (al-Muslimûn) dan orang-orang Islam perempuan (al-Muslimât) dan laki-laki beriman (al-mu'minûn) dan perempuan beriman (almu'minât). Demikian pula halnya dengan kata-kata ganti untuk laki-laki (damîr mudhakerar) dan kata ganti untuk perempuan (damîr mu'annath). ${ }^{9}$

Dengan demikian, merupakan sebuah tantangan yang tidak mudah dalam memaknai kesetaraan laki-laki dan perempuan jika kita mengacu kepada dalil-dalil normatif, termasuk al-Qur'ân. Meskipun demikian, tetap bisa dibuktikan bahwa al-Qur'ân mendukung idealitas kesetaraan antara laki-laki dan perempuan. Sebagai contoh adalah ayat 35 dalam surat al-Aḥzâb [33]. Konsep kesetaraan dalam ayat ini mengisyaratkan dua pengertian. Pertama, al-Qur'ân mengakui martabat pria dan wanita dalam kesejajaran tanpa membedakan jenis kelamin. Kedua, pria dan wanita mempunyai hak dan kewajiban yang sejajar di segala bidang.

Meskipun demikian, pandangan inferior bahwa perempuan adalah makhluk yang lemah juga disosialisasikan atas nama agama, seperti yang tertera dalam ayat 34 surat al-Nisâ' [4]. Interpretasi terhadap ayat tersebut menunjukkan bahwa kaum pria, karena sebagai pemimpin, mempunyai hak istimewa daripada kaum perempuan, maka perempuan adalah kaum yang lemah sebagai hamba sahayanya atau pelayan bagi kaum laki-laki. Dalam konteks ini, hampir semua tafsir al-Qur'ân mengalami bias gender yang antara lain disebabkan karena pengaruh budaya Timur Tengah yang androcentric, di mana sumber

9 Nasaruddin Umar, Argumen Kesetaraan Gender Perspektif Al-Quran (Jakarta: Paramadina, 1999), 13-14. 
konsep, model dan teori dalam kajian agama sangat "laki-laki sentris". ${ }^{10}$

Boleh jadi memang pada ayat-ayat seperti telah disebutkan, dimaksudkan tidak untuk merendahkan kaum perempuan, tetapi hanya merujuk kepada fungsi dan peran sosial berdasar jenis kelamin (gender roles). Hal ini karena pada umumnya ayat-ayat al-Qur'ân mempunyai sabab al-nu₹ûl, sehingga sifatnya sangat bistorical. ${ }^{11}$ Oleh karena itulah memahami ajaran al-Qur'ân hanya melalui penafsiran sebagaimana yang ditafsirkan oleh ulama salaf tidaklah cukup. Hal ini karena kondisi sosial masyarakat saat ini tidak lagi seperti pada masa dulu. Selain itu bukan saja karena al-Qur'ân harus diyakini berdialog dengan setiap generasi, namun juga harus dipelajari dan dipikirkan. Sementara hasil pemikiran (termasuk penafsiran) selalu dipengaruhi oleh beberapa faktor, seperti kondisi pengalaman, ilmu pengetahuan, latar belakang pendidikan yang berbeda dari satu generasi ke generasi lainnya, bahkan antara pemikir satu dan pemikir lainnya pada suatu generasi. ${ }^{12}$

Sejarah telah mencatat dan mengakui bahwa Islam merupakan agama sekaligus sistem sosial yang pertama mengakui status manusiawi dalam diri wanita dengan memberi mereka martabat dan kehormatan yang tinggi, memberi mereka hak yang sama dengan pria dalam segala aspek dan pada saat yang sama menghapuskan segala diskriminasi yang didasarkan pada jenis kelamin (sex). Namun, hal itu hanya berjalan sementara waktu; semua berubah ketika Nabi dan para sahabatnya telah tiada. Kaum Muslim, dalam hal ini mufassir, mulai menginterpretasikan ajaran-ajaran Tuhan dan Nabi-Nya, yaitu dengan menafsirkan ayat-ayat al-Qur'ân di mana kewajiban dan hak tentang wanita pada awalnya secara proporsional diberikan, justru dengan tafsiran yang baru membuat wanita kembali diperbudak dari sebelumnya. Di samping itu, adanya faham-faham misogynic (yang membenci wanita) di luar Islam yang masuk ke dalam berbagai literatur, seperti riwayat isrầilîyat, yang dijadikan rujukan utama dalam menafsirkan al-Qur'ân, ${ }^{13}$ membuka peluang yang semakin luas bagi terjadinya bias gender dalam memahami ajaran-ajaran agama.

\footnotetext{
10 King Ursula, "Introduction: Gender and the Study of Religion, dalam "Religion and Gender (USA: Blackwell, 1995), 89.

${ }^{11}$ Umar, Argumen Kesetaraan Gender, 111.

12 Zaitunah Subhan, Tafsir Kebencian: Studi Bias Gender dalam Tafsir al-Qur'an (Yogyakarta: LKIS, 1999), 8.

${ }^{13}$ Umar, Argumen Kesetaraan Gender, 280-290.
} 
Sehingga kesimpulan yang bisa diambil ialah bahwa status wanita lebih inferior terhadap kaum pria dan dengan alasan yang sama mereka mempunyai hak yang lebih sedikit. ${ }^{14}$

Menurut Riffat Hassan, adanya diskriminasi dan segala macam bentuk ketidakadilan gender yang menimpa kaum wanita dalam lingkungan umat Islam berakar dari pemahaman yang "keliru" dan bias patriarkhi terhadap sumber ajaran Islam, yaitu kitab suci alQur'ân. ${ }^{15}$ Oleh karena itu, bagi Riffat, salah satu upaya strategis yang harus dilakukan dewasa ini adalah membaca kembali pewartaan alQur'ân dengan melibatkan optik wanita. Hanya melalui "rekonstruksi hermeneutik" semacam inilah, spirit egalitarian al-Qur'ân yang revolusioner dapat kembali ditemukan, dan "suara-suara wanita" dapat kembali didengar. ${ }^{16}$ Pertanyaan yang muncul adalah "bagaimana sebenarnya relasi pria dan wanita dalam Islam sendiri?"

Dalam al-Qur'ân sendiri tidak ditemukan ayat yang secara detail menerangkan tentang penciptaan (asal-usul) perempuan, kecuali pada ayat al-Nisâ ayat 1 yang selalu diandalkan untuk melegitimasi bahwa perempuan diciptakan dari bagian (tulang rusuk) laki-laki. Hal ini terbukti dengan banyaknya kitab tafsir mu'tabar dari kalangan jumbûr yang menafsirkan kata nafs wâhidah (a single self) —dalam ayat tersebut-dengan Adam dan kata zawj (pair) dengan Hawa, istri Adam. Penafsiran ini ditemukan, misalnya, dalam Tafsîr al-Mîzân, Tafsîr Ibn Kathîr, Tafsîr al-Baḥr al-Muhît, Tafsîr Rûh al-Bayân, Tafsîr alKashshâf, Tafsîr al-Sa 'ûd, Tafsîr Jâmi' al-Bayân dan Tafsîr al-Marâghî.

a. Perempuan sebagai individu

Dukungan untuk berbuat baik oleh al-Qur'ân diberikan tanpa membedakan etnis serta mengandalkan prestasi dan kualitas saja. Hal ini karena al-Qur'ân tidak menganut faham the second sex yang memberikan keutamaan kepada jenis kelamin tertentu, atau the first ethnic, yang mengistimewakan suku tertentu. ${ }^{17}$ Al-Qur'ân menyoroti perempuan sebagai individu. Dalam hal ini terdapat perbedaan antara perempuan dalam kedudukannya sebagai individu dengan perempuan sebagai anggota masyarakat. Al-Qur'ân memperlakukan baik individu

\footnotetext{
${ }^{14}$ Qamaruddin Khan, Status of Women in Islam (New Delhi: Sterling Publishers Put. Ltd., 1990), 13.

15 Abdul Mustaqim, "Pemikiran Riffat Hassan tentang Feminisme", Jurnal Studi Islam Profetika, Vol. 3, No. 1 (Januari, 2001), 47.

${ }^{16}$ Ibid., 50.

${ }^{17}$ Umar, Argumen Kesetaraan Gender, 110.
} 
perempuan dan laki-laki adalah sama, karena hal ini berhubungan antara Allah dan individu perempuan atau laki-laki tersebut, sehingga terminologi kelamin (sex) tidak diungkapkan dalam masalah ini. ${ }^{18}$

Pernyataan-pernyataaan al-Qur'ân tentang posisi dan kedudukan perempuan dapat dilihat dalam beberapa ayat sebagaimana berikut: pertama, perempuan adalah makhluk ciptaan Allah yang mempunyai kewajiban sama untuk beribadat kepada-Nya sebagaimana termuat dalam surat al-Dhâriyât ayat 56. Ayat tersebut jelas menegaskan bahwa Tuhan menciptakan alam semesta, termasuk manusia, secara berpasang-pasangan. Jika sesuatu diciptakan sebagai pasangan, jelaslah bahwa yang satu tidak lengkap tanpa kehadiran yang lain. Sehingga di sini aspek komplementer menjadi sangat kuat, baik bagi manusia yang berjenis kelamin laki-laki maupun perempuan. Kedua, perempuan adalah pasangan bagi kaum laki-laki termuat dalam surat al-Naba' ayat 8. Perempuan bersama-sama dengan kaum laki-laki juga akan mempertanggungjawabkan secara individu setiap perbuatan dan pilihannya termuat dalam surat Maryam ayat 93-95. Ketiga, perempuan mukminat yang beramal saleh dijanjikan Allah untuk dibahagiakan selama hidup di dunia dan abadi di surga. Hal ini sebagaimana termuat dalam surat al-Nahl ayat $97 .{ }^{19}$

Dalam ayat-ayatnya bahkan al-Qur'ân tidak menjelaskan secara tegas bahwa Hawa diciptakan dari tulang rusuk Adam, sehingga karenanya kedudukan dan statusnya lebih rendah. Atas dasar itu prinsip al-Qur'ân terhadap kaum laki-laki dan perempuan adalah sama, di mana, misalnya, hak istri diakui secara adil (equal) dengan hak suami. Dengan kata lain, laki-laki memiliki hak dan kewajiban atas perempuan dan kaum perempuan juga memiliki hak dan kewajiban atas laki-laki. Karena hal tersebutlah maka al-Qur'ân dianggap memiliki pandangan yang revolusioner terhadap hubungan kemanusiaan, yakni memberikan keadilan hak antara laki-laki dan perempuan. $^{20}$

b. Perempuan dan hak kepemilikan

Islam datang dengan doktrin mengenai hubungan manusia yang berlandaskan keadilan, termasuk di dalamnya kesetaraan kedudukan

\footnotetext{
18 Ibid., 4.

19 Nurjannah Ismail, Perempuan dalam Pasungan: Bias Laki-laki dalam Penafsiran (Yogyakarta: LKIS, 2003), 64.

${ }^{20}$ Lihat M. Hidayat Nur Wahid, "Kajian atas Kajian Dr. Fatima Mernissi tentang Hadis Misogini”, dalam Membincang Feminisme: Diskursus Gender Persfektif Islam, ed. Mansour Fakih (Surabaya: Risalah Gusti, 1996), 3-35.
} 
laki-laki dan perempuan dalam beberapa aspek penting kehidupan. Salah satu aspek tersebut adalah hak terkait dengan ekonomi, yakni untuk memiliki harta kekayaannya sendiri, sehingga tidak suami maupun bapaknya dapat mencampuri hartanya. Hal tersebut secara tegas disebutkan dalam surat al-Nisâ' ayat 32. Kepemilikan atas kekayaannya tersebut termasuk yang didapat melalui warisan ataupun yang diusahakannya sendiri. Oleh karena itu, mahar atau maskawin dalam Islam harus dibayar untuk si perempuan sendiri, bukan untuk orang tua dan tidak bisa diambil kembali oleh si suami.

Sayyid Qutb menegaskan bahwa tentang kelipatan bagian kaum pria dibanding kaum perempuan dalam hal harta warisan, sebagaimana yang tertulis dalam al-Qur'ân, maka rationalenya adalah watak kaum pria dalam kehidupan di mana ia menikahi wanita dan bertanggungjawab terhadap nafkah keluarganya selain ia juga bertanggungjawab terhadap segala sesuatu yang berkaitan dengan keluarganya itu. Itulah sebabnya ia berhak memperoleh bagian sebesar bagian untuk dua orang perempuan. Sementara itu kaum wanita, bila ia bersuami, maka seluruh kebutuhannya ditanggung oleh suaminya, sedangkan bila ia masih gadis atau sudah janda, maka kebutuhannya terpenuhi dengan harta warisan yang ia peroleh, ataupun kalau tidak demikian, ia bisa ditanggung oleh kaum kerabat laki-lakinya. Jadi perebedaan yang ada di sini hanyalah perbedaan yang muncul karena karakteristik tanggung jawab mereka yang mempunyai konsekwensi logis dalam pembagian warisan. ${ }^{21}$ Artinya, perbedaan porsi warisan ini bukan merupakan bentuk diskriminsi atas perempuan.

Bahkan Islam memberi jaminan semua hak kepada kaum wanita dengan semangat kemanusiaan yang murni, bukan disertai dengan tekanan ekonomis atau materialis. Islam justru memerangi pemikiran yang mengatakan bahwa kaum wanita hanyalah alat yang tidak perlu diberi hak-hak. Islam memerangi kebiasan penguburan hidup anakanak perempuan, dan mengatasinya dengan semangat kemanusiaan yang murni, sehingga ia mengharamkan pembunuhan seperti itu. ${ }^{22}$

c. Perempuan dan pendidikan

Islam memerintahkan baik laki-laki maupun perempuan agar berilmu pengetahuan dan tidak menjadi orang yang bodoh. Allah sangat mengecam orang-orang yang tidak berilmu pengetahuan, baik

${ }^{21}$ Sayyid Quthb, Keadilan Sosial dalam Islam (Bandung: Penerbit Pustaka, 1984), 71 74.

22 Ibid., 80. 
laki-laki maupun perempuan. Hal ini sebagaimana disinyalir dalam surat al-Zumar ayat 9. Kewajiban menuntut ilmu juga ditegaskan oleh Nabi Muhammad melalui sabdanya yang artinya "Menuntut ilmu merupakan suatu kewajiban atas setiap Muslim laki dan perempuan." (HR. Muslim). Dengan demikian dapat dikatakan bahwa Islam justru menumbangkan suatu sistem sosial yang tidak adil terhadap kaum perempuan dan menggantikannya dengan sistem yang mengandung keadilan. Islam memandang perempuan adalah sama dengan laki-laki dari segi kemanusiannya. Islam memberi hak-hak kepada perempuan sebagaimana yang diberikan kepada kaum laki-laki dan membebankan kewajiban yang sama kepada keduanya.

\section{Pengarusutamaan Gender dalam Kebijakan Pendidikan Islam}

a. Strategi Pengarusutamaan Gender

Pengarusutamaan gender adalah suatu strategi untuk mencapai kesetaraan dan keadilan gender melalui kebijakan dan program yang memperhatikan pengalaman, aspirasi, kebutuhan dan permasalahan perempuan dan laki-laki untuk memperoleh akses kepada, berpartisipasi dalam, mempunyai kendali atas dan mendapatkan manfaat yang sama dalam proses pembangunan. Jadi pengarusutamaan gender dilakukan dalam semua tahap, mulai dari perencanaan, pelaksanaan, pemantauan dan evaluasi dari semua kebijakan dan program pembangunan.

Agenda pengarusutamaan gender sebenarnya muncul dalam strategi-strategi perjuangan untuk mewujudkan keadilan sosial dalam perspektif kaum perempuan. Kritik kontemporer gender berawal dari studi empirik tentang perbedaan analisis mengenai tatanan sosial dan perilaku manusia di mana gender merupakan elemen integral. Strategi pertama atau disebut juga strategi yang tertua, yaitu strategi "meningkatkan peran wanita" melalui peran global yang dikenal sebagai Women in Development (WID) atau melibatkan kaum perempuan dalam pembangunan. ${ }^{23}$ Strategi ini didasarkan pada analisis yang berfokus pada kaum perempuan dengan asumsi bahwa permasalahan kaum perempuan berakar pada rendahnya kualitas sumber daya kaum perempuan sendiri, dan hal itu mengakibatkan mereka tidak mampu berkompetisi dengan kaum lelaki. Agenda mengejar ketertinggalan kaum perempuan ini bertumpu pada pemahaman modernisasi.

${ }^{23}$ The United Nation, The Millennium Development Goals Report 2013 (New York: The United Nation), 142. 
Secara mendasar, PUG, menurut Saraswati (2013), ${ }^{24}$ merupakan sebuah strategi, bukan tujuan. Lebih lanjut ia menyatakan bahwa PUG dirumuskan agar desain, implementasi, monitoring, dan evaluasi kebijakan dan program di seluruh ranah politik, ekonomi, sosial, dan budaya dapat terwujud. Sedangkan tujuan utamanya adalah mewujudkan keadilan gender. PUG merupakan sarana agar semua program pembangunan dapat dilaksanakan dengan mempertimbangkan kesempatan dan akses perempuan terhadap program pembangunan. Selain akses dan kesempatan, perempuan juga perlu mendapatkan kendali (control) dan manfaat (outcome) program pembangunan demi terwujudnya keadilan gender.

Konsep PUG pertama kali muncul dalam konferensi Perserikatan Bangsa-Bangsa (PBB) untuk Perempuan IV di Beijing tahun 1995. Pada saat itu berbagai area kritis yang perlu menjadi perhatian pemerintah dan masyarakat di seluruh dunia untuk mewujudkan kesetaraan gender mulai dipetakan. Terdapat 12 wilayah kritis yang harus ditempuh dalam upaya pemberdayaan perempuan di negaranegara anggota PBB. Wilayah kritis tersebut adalah: 1) perempuan dan kemiskinan; 2) pendidikan dan pelatihan untuk perempuan; 3) perempuan dan kesehatan; 4) kekerasan terhadap perempuan; 5) perempuan dan konflik bersenjata; 6) perempuan dan ekonomi; 7) perempuan dalam kekuasaan dan pengambilan keputusan; 8) mekanisme institusional untuk kemajuan perempuan; 9) hak asasi perempuan; 10) perempuan dan media; 11) perempuan dan lingkungan; dan 12) anak perempuan. ${ }^{25}$

PUG diadopsi secara resmi di Indonesia sejak tahun 2000 dengan keluarnya Instruksi Presiden (Inpres) Nomor 9 Tahun 2000. Inpres ini merupakan suatu dasar hukum untuk pelaksanaan PUG yang merupakan suatu bentuk komitmen pemerintah Indonesia dalam mengikuti kesepakatan internasional dan juga desakan masyarakat luas, khususnya para pakar atau pemerhati masalah gender, agar pemerintah melakukan tindakan-tindakan nyata dalam usaha mempercepat keadilan dan kesetaraan gender.

Hal ini dilakukan mengingat akar masalah ketidakadilan yang terjadi selama ini mungkin saja berasal dari praktik kebijakan dan program pembangunan (selain masalah budaya), yang menyebabkan

\footnotetext{
${ }^{24}$ Lihat M. Daly, "Gender Mainstreaming in Theory and Practice", Social Politics: International Studies in Gender, State and Society, Vol. 12, No. 3 (2005), 433-450.

${ }^{25}$ Ibid., 408.
} 
ada kelompok yang dirugikan atau diperlakukan tidak adil, dan kelompok lainnya menikmati keuntungan dari proses pembangunan tersebut. Sebagai contoh dalam proses sosialisasi mengenai bagaimana menjadi perempuan yang ideal, seringkali keluarga, sekolah, bacaan dan televisi yang menjadi sumber informasi menegaskan suatu bentuk hubungan antara laki-laki dan perempuan di mana laki-laki tetap ditonjolkan sedangkan perempuan cenderung dihubungkan dengan kegiatan domestik. ${ }^{26}$

Strategi PUG perlu ditempuh demi mewujudkan kesetaraan dan keadilan gender dalam kehidupan berkeluarga, bermasyarakat, berbangsa, dan bernegara. Cakupan PUG dalam Inpres tersebut di atas meliputi perencanaan, termasuk di dalamnya perencanaan yang responsif gender (gender budgeting), pelaksanaan, pemantauan dan evaluasi. Agar menjadi lebih konkret, PUG kemudian diadopsi pula pada Rencana Pembangunan Jangka Panjang Nasional (RPJMN) 2004-2009 dan RPJMN 2010-2014. Pada RPJMN 2010-2014, PUG merupakan satu dari Kebijakan Pengarusutamaan yang harus diwujudkan, selain pengarusutamaan tentang pembangunan berkelanjutan (sustainable development) dan tata kelola pemerintahan yang baik (good governance). Khusus untuk PUG, sasaran utamanya adalah peningkatan kualitas hidup perempuan, penanganan kekerasan terhadap perempuan, dan peningkatan efektivitas kelembagaan dalam melaksanakan PUG di tingkat nasional, propinsi, maupun kabupaten/kota.

Pengadopsian PUG di tingkat yang lebih rendah didukung pula dengan sejumlah kebijakan yang terkait dengan perencanaan dan penganggaran pembangunan yaitu Keputusan Menteri Dalam Negeri Nomor 15 Tahun 2008 tentang Pedoman Umum Pelaksanaan Pengarusutamaan Gender dalam Pembangunan di Daerah yang diperbaharui dengan Peraturan Menteri Dalam Negeri Nomor 67 Tahun 2011. Pedoman ini mengatur bahwa PUG harus tercermin dalam dokumen-dokumen rencana pembangunan dan kelembagaan PUG.

Ada tiga prinsip utama dalam PUG yaitu: pertama, menempatkan individu sebagai manusia seutuhnya di mana laki-laki dan perempuan mempunyai hak yang sama dalam mendapatkan perlindungan. Kedua adalah prinsip demokrasi di mana laki-laki dan perempuan

${ }^{26}$ Ace Suryadi dan Ecep Idris, Kesetaraan Gender dalam Bidang Pendidikan (Bandung: Genesindo, 2004), 78. 
mempunyai hak untuk menyuarakan aspirasi dan kebutuhan mereka. Ketiga adalah prinsip fairness, justice and equity (pemerataan, penegakan hukum dan kesetaraan). ${ }^{27}$ Menurut Rao dan Kelleher, PUG harus terjadi dalam empat tingkat, yaitu individual atau personal, sosial, nilai-nilai informal yang terbentuk dalam budaya dan praktik-praktik agama serta aturan formal institusi. ${ }^{28}$

b. Kebijakan pendidikan berprespektif gender

Secara garis besar, tujuan kebijakan berprespektif gender merupakan tujuan kebijakan umum yang bermaksud memperbaiki kualitas perempuan dan laki-laki. Sedangkan tujuan kebijakan yang "digenderkan" adalah tujuan kebijakan umum yang tidak secara eksplisit menyebutkan langkah pengurangan ketidakseimbangan relasi gender dalam objek sasaran yang ingin dituju. Sementara itu tujuan kebijakan responsif gender adalah kebijakan yang dimaksudkan untuk mengurangi kesenjangan antara laki-laki dan perempuan dalam beberapa aspek pembangunan. Adapaun tujuan khusus untuk perempuan adalah kebijakan yang memang ditujukan secara khusus untuk kesejahteraan perempuan di mana secara khusus kebijakan itu melakukan pemberdayaan untuk perempuan.

Suatu kebijakan pendidikan dikatakan berkualitas baik dalam perspektif gender apabila menetapkan tujuan atau sasaran untuk memperkecil kesenjangan gender di bidang pendidikan. ${ }^{29}$ Kualitas kebijakan pendidikan dikategorikan dalam tiga klasifikasi, yaitu netral gender, potensial bias gender, dan responsif gender. ${ }^{30}$ Ketiga klasifikasi tersebut dijelaskan dalam tabel di bawah ini.

Tabel

Kebijakan sensitif gender

\begin{tabular}{|l|l|}
\hline Netral gender & $\begin{array}{l}\text { Kebijakan/program tidak memihak pada salah satu } \\
\text { jenis kelamin. }\end{array}$ \\
\hline $\begin{array}{l}\text { Potensial bias } \\
\text { gender }\end{array}$ & $\begin{array}{l}\text { Kebijakan/program terkesan netral gender, tetapi } \\
\text { berpotensi untuk diimplementasikan secara bias } \\
\text { gender (merugikan salah satu jenis kelamin). }\end{array}$ \\
\hline $\begin{array}{l}\text { Responsif } \\
\text { gender }\end{array}$ & $\begin{array}{l}\text { Kebijakan/program kegiatan sudah memperhi- } \\
\text { tungkan kepentingan laki-laki dan perempuan. }\end{array}$ \\
\hline
\end{tabular}

${ }^{27}$ Sinta R. Dewi, "Pengarusutamaan Gender", Jurnal Perempuan, Edisi ke-50 Jakarta: Yayasan Jurnal Perempuan, 2006), 6-7.

28 Ibid., 14.

${ }^{29}$ Ismi Dwi Astuti Nurhaeni, Reformasi Kebijakan Pendidikan Menuju Kesetaraan dan Keadilan Gender (Surakarta: LPP-UNS Press, 2009), 135.

${ }^{30}$ Ibid., 15. 
Kebijakan responsif gender memberikan kesempatan bagi perempuan yang mempunyai kemampuan dan keahlian untuk berperan aktif dalam rutinitas sebagaimana laki-laki. Namun demikian, persoalan pemenuhan hak-hak tersebut kelihatannya masih minim dan bahkan sangat jarang ada laki-laki begitu memperhatikan kemampuan dan keahlian yang dimiliki oleh perempuan. Oleh karenanya sangat wajar jika di kemudian hari banyak terjadi ketidakadilan gender, bahkan kesenjangan dari segi peran, hak dan kewajiban antara laki-laki dan perempuan, termasuk dalam bidang pendidikan. Keadilan dan kesetaraan gender dalam bidang pendidikan dapat dipenuhi jika ada jaminan yang pasti dari undang-undang atau hukum. Hal ini karena relasi gender tidak semata lahir dari kesadaran individu, tetapi juga bergantung pada faktor ekonomi, sosial dan lingkungan yang sehat dan dinamis.

Ada beberapa strategi untuk menjalankan kebijakan dalam bidang pendidikan agar tidak bias gender. Nugroho ${ }^{31}$ menganjurkan empat strategi pokok sebelum menjalankan kebijakan agar tidak bias gender, yaitu: pertama, harus dipastikan bahwa para pelaksana memahami bahwa kebijakan tersebut adalah kebijakan yang pro-gender. Kedua, harus dipastikan bahwa ada mekanisme reward dan punishment bagi pematuh dan pelanggarnya. Ketiga, mempunyai ukuran kinerja yang pro-gender. Keempat, mengevaluasi kinerja dan persyaratan pokok yang harus dipenuhi, antara lain adanya kesamaan konsepsi tentang gender dan kesetaraan gender, adanya kecukupan kemampuan untuk melakukan evaluasi dalam konteks kesetaraan gender dan alat ukur evaluasi itu sendiri harus mampu mencerminkan pelaporan tentang sejauh mana kesetaraan gender dicapai oleh sebuah kebijakan publik tertentu.

Model dan transformasi kebijakan yang dikemukakan oleh Nugroho $^{32}$ menyebutkan bahwa pada kondisi awal kesetaraan gender dalam bidang pendidikan tidak tercapai, karena ada kebijakankebijakan yang bias gender. Kebijakan ini dapat ditransformasikan secara langsung menjadi kebijakan netral gender ataupun melalui kebijakan spesifik gender untuk kemudian ditransformasikan menjadi kebijakan netral gender. Namun demikian, pada akhirnya, harus ada

31 R. D. Nugroho, Public Policy: Teori Kebijakan, Analisis Kebijakan, Proses Kebijakan, Perumusan, Implementasi, Evaluasi, Revisi, Risk Management dalam Kebijakan Publik (Jakarta: PT Elex Media Komputindo, 2012), 254.

32 Ibid., 256. 
kebijakan pengontrol yang mengontrol kebijakan netral gender agar tidak bias dalam implementasinya yang secara efektif dilakukan dengan mempertahankan maupun menyempurnakan kebijakan spesifik gender.

\section{c. Strategi Pengarusutamaan Gender dalam Kebijakan Pendidikan Islam}

Kebijakan yang telah direkomendasikan untuk dipilih oleh policy makers bukanlah jaminan bahwa kebijakan tersebut pasti berhasil dalam implementasinya. Implementasi kebijakan strategis dan kebijakan mutu dalam bidang pendidikan dapat dijabarkan menjadi program-program dan dilaksanakan dengan cepat, sesuai dengan kondisi dan potensi lembaga pendidikan yang ada. Apabila terdapat aspek dalam kebijakan tersebut yang mempunyai kekurangan, maka bisa dilakukan perbaikan. Semuanya tentu harus mengacu pada rumusan kebijakan yang telah ditetapkan, sehingga tujuan yang diharapkan dapat tercapai.

Pengarusutamaan gender dalam kebijakan pendidikan sejalan dengan upaya pencapaian salah satu sasaran Millennium Development Goals (MDGs), yaitu kesetaraan dan keadilan gender. Untuk mencapai target tersebut, pembangunan pendidikan perlu tetap diarahkan pada upaya menangani persoalan kesenjangan gender yang terjadi pada sektor pendidikan, yang menyangkut isu akses, pemerataan, perluasan, dan keadilan dalam pendidikan, mutu dan relevansi serta efisiensi manajemen pendidikan. ${ }^{33}$ Dalam kaitan dengan isu mutu dan relevansi pendidikan, arah dan kebijakan yang diambil, antara lain: pertama, menyempurnakan kurikulum dan memperbaiki materi ajar agar lebih sensitif gender. Kedua, meningkatkan kualitas tenaga pendidik dan kependidikan, sehingga memiliki pemahaman yang memadai mengenai masalah gender, bersikap sensitif, serta menerapkannya dalam proses pembelajaran.

Dalam kaitan dengan manajemen pendidikan, arah dan kebijakan yang diambil antara lain: pertama, melakukan analisis terhadap kebijakan dan peraturan perundangan yang masih bias gender. Kedua, merumuskan dan menetapkan kebijakan dan peraturan perundangundangan pendidikan yang berwawasan gender. Ketiga, meningkatkan kapasitas institusi pengelola pendidikan yang memiliki kemampuan

\footnotetext{
33 I. Satyawan, "Gender Mainstreaming in Education: An Indonesian Experience", dalam S. Tarjana (ed.), Pergeseran Paradigma Pembangunan Pemberdayaan Perempuan Menuju Pengarusutamaan Gender (Solo: Cakra Books, 2007), 56.
} 
untuk merencanakan, menyusun kebijakan, strategi dan program pendidikan berwawasan gender secara efektif dan efisien. Keempat, mengembangkan pusat-pusat studi gender serta memperkuat pusatpusat studi lainnya sehingga berwawasan gender sebagai mitra pemerintah pusat dan daerah dalam pembangunan pendidikan berwawasan gender.

Arah dan kebijakan tersebut dapat dilaksanakan melalui lima strategi utama, yaitu: ${ }^{34}$ pertama, penyediaan akses pendidikan yang adil dan bermutu pada setiap jenjang, jalur, dan jenis pendidikan bagi anak laki-laki dan perempuan baik melalui pendidikan persekolahan maupun pendidikan luar sekolah. Kedua, penyediaan akses pendidikan kesetaraan bagi penduduk usia dewasa yang tidak dapat mengikuti pendidikan persekolahan. Ketiga, peningkatan penyediaan pelayanan pendidikan keaksaraan dalam rangka meningkatkan tingkat keaksaraan terutama penduduk perempuan. Keempat, peningkatan koordinasi, informasi dan edukasi dalam rangka mengarusutamakan pendidikan berwawasan gender dalam berbagai kebijakan pendidikan. Kelima, pengembangan kelembagaan institusi pendidikan baik di tingkat pusat maupun daerah mengenai pendidikan berwawasan gender melalui peningkatan kapasitas (capacity building).

Sementara itu integrasi kesetaraan gender ke dalam bidang pendidikan Islam dapat dilakukan melalui: ${ }^{35}$ pertama, kebijakan PUG bidang pendidikan Islam; kedua, manajemen dan budaya di tingkat satuan pendidikan Islam; ketiga, kurikulum dan pembelajaran pendidikan Islam di dalam kelas; keempat, peran serta masyarakat dan komite madrasah; kelima, sinergi pendidikan Islam dengan pendidikan di bawah naungan Kemendiknas. Implementasi PUG dalam bidang pendidikan Islam sangat ditentukan oleh kebijakan PUG yang mengacu pada terpenuhinya unsur-unsur atau yang lazim disebut "komponen kunci"36, yaitu komitmen politik, kelembagaan atau struktur, sumber daya, sistem infomasi dan data, alat analisis atau gender analysis skill dan dukungan masyarakat.

34 Tim Penyusun, Panduan Pelaksanaan Inpres Nomor 9 Tabun 2000 tentang Pengarusutamaan Gender dalam Pembangunan Nasional Jakarta: Kementerian Pemberdayaan Perempuan, 2002), 98-102.

35 Tim Penyusun, Panduan Pengarusutamaan Gender Bidang Pendidikan: Buku II Kebijakan Pengarusutamaan Gender Bidang Pendidikan (Malang: Indonesia-Australia Partnership in Basic Education, 2007), 34-45.

${ }^{36}$ Lihat Tim Penyusun, Panduan Pelaksanaan Inpres Nomor 9. 
Kemeterian Agama sebagai pemegang kebijakan dalam pendidikan Islam di Indonesia, dalam kaitannya dengan isu ini, dapat menerapkan dua pendekatan dari strategi pengarusutamaan gender. Madden dan Dillon, sebagaimana dikutip oleh Taylor, mengidentifikasi pendekatan ini sebagai pendekatan "pengaturan agenda" dan pendekatan "pemersatu atau peran." Pendekatan pengaturan agenda dapat didefinisikan sebagai pelaksana pengarusutamaan gender yang ideal. ${ }^{37}$ Tujuannya adalah untuk mengurangi kesenjangan yang ada di antara perempuan dan laki-laki. Taylor menegaskan bahwa dalam pengaturan agenda, perspektif gender dan tujuan kesetaraan gender dipandang sebagai pusat dari semua kegiatan dalam pengembangan kebijakan, penelitian, advokasi, dialog, undangundang, alokasi sumber daya, perencanaan dan pemantauan program dan proyek dengan cara memastikan bahwa lembaga-lembaga, kebijakan dan program merespons kebutuhan dan kepentingan perempuan serta laki-laki lalu mendistribusikan manfaat secara adil antara perempuan dan laki-laki. ${ }^{38}$

Pendekatan pemersatu atau peran adalah pendekatan yang paling sering digunkan oleh lembaga-lembaga internasional. Pendekatan ini berupaya untuk membangun isu-isu gender ke dalam kerangka kerja pembangunan dan intervensi yang ada dan oleh karenanya memandang pengarusutamaan gender dari sudut pandang yang berbeda. Dengan menggunakan pendekatan ini, agenda pembangunan secara kesuluruhan tidak mengalami perubahan dan disesuaikan untuk mencoba mengatasi masalah-masalah yang berkaitan dengan wanita. ${ }^{39}$ Dengan demikian, perempuan sedapat mungkin dimasukkan ke dalam banyak sektor dan berbagai program yang ada, namun prioritas sektor dan program tidak berubah hanya karena masalah gender.

\section{Gender Mainstreaming dalam Kebijakan Pendidikan Islam Tahun 2010-2014}

Direktorat Jenderal Pendidikan Islam Kementerian Agama sudah mempunyai payung hukum yang tegas sebagai dukungan politik dari pemerintah dalam rangka memberi pedoman bagi Kementerian

37 M. Taylor, "Gender and Development", dalam Banúlacht: Women in Ireland in Global Solidarity,

dalam

http://www.banulacht.ie/docs/Taylor_Gender_and_Development.doc

(Diakses 12 Maret 2015).

${ }^{38} \mathrm{Ibid}$.

${ }^{39}$ Ibid. 
Agama dalam menyusun perencanaan dan penganggaran yang responsif gender di bidang pendidikan Islam. ${ }^{40}$ Pengintegrasian aspek gender ke dalam perencanaan dan penganggaran yang berbasis kinerja merupakan suatu kesatuan yang tidak terpisahkan. Aspek gender bisa diintegrasikan di dalam setiap tahapan perencanaan dalam berbagai bentuk, baik identifikasi, perencanaan, implementasi, monitoring maupun evaluasi. Pada tahap identifikasi, potensi dan kebutuhan, aspek gender masuk dalam bentuk analisis situasi. Pada perencanaan kebijakan, maka formulasi kebijakan dilakukan dengan memperhatikan gender. Implementasi kebijakan dilaksanakan dengan memperhatikan partisipasi laki-laki dan perempuan. Adapun kegiatan monitoring dan evaluasi menggunakan berbagai indikator yang sensitif gender. $^{41}$

Meskipun demikian, saat ini belum ada petunjuk terkait strategi yang jelas dalam gender mainstreaming dalam pendidikan Islam. Selain itu, keberadaan staf yang memiliki pemahaman gender yang baik juga masih terbatas. Sebagai salah satu rekomendasi kunci dari tulisan ini adalah harapan bahwa Kementerian Agama, khususnya, mengembangkan strategi yang jelas terkait kesetaraan gender dalam sektor pendidikan. Harus diakui bahwa program-program yang diimplementasikan oleh Kemenag dalam bidang pendidikan Islam antara tahun 2010 sampai dengan 2014, sebagaimana diantaranya akan dipaparkan di bawah ini, telah menyentuh aspek kesetaraan gender.

a. Program Beasiswa Santri Berprestasi (PBSB) 2013

Program Beasiswa Santri Berprestasi (PBSB) adalah program afirmasi perluasan akses santri pondok pesantren terhadap perguruan tinggi negeri dan swasta ternama di negeri ini. ${ }^{42}$ Program ini digulirkan pertama kali oleh Direktorat Pendidikan Diniyyah dan Pondok Pesantren Kementerian Agama pada tahun 2005 dengan menggandeng dua perguruan tinggi negeri yaitu UIN Syarif Hidayatullah dan Institut Pertanian Bogor.

\footnotetext{
40 Lihat Peraturan Menteri Negara Pemberdayaan Perempuan dan Perlindungan Anak Republik Indonesia Nomor 12 Tahun 2010 tentang Pedoman Perencanaan dan Penganggaran pada Pendidikkan Islam yang Responsif Gender, 8-17.

41 Lihat Kementerian Perencanaan Pembangunan Nasional/Badan Perencanaan Pembangunan Nasional (BAPPENAS), Evaluasi Parub Waktu RPJMN 2010-2014 (Jakarta: BAPPENAS, 2013), 152-155.

42 Tim Penyusun, Grand Desain Program Beasiswa Santri Berprestasi 2005-2014: Mengubah Takdir Bangsa 2025 (Jakarta: Direktorat Pendidikan Diniyah dan Pondok Pesantren Direktorat Jenderal Pendidikan Islam Kementerian Agama RI, t.th.), 1-7.
} 
Fakta yang menunjukkan adanya ketidakpuasan masyarakat terhadap situasi pendidikan yang mengalami kerancuan kiranya sudah cukup menjadi pelajaran berharga bagi dunia pendidikan di negeri ini, khususnya pendidikan Islam. Oleh karena itu, penggabungan fungsi pesantren dan perguruan tinggi dapat dipandang mampu menumbuhkan pemikiran kreatif untuk menghasilkan formulasi keilmuan yang utuh, khususnya yang terkait dengan pengembangan dunia pendidikan. Bentuk implementasi dari fungsi tersebut adalah upaya-upaya praktis dan sistematis, seperti pendampingan, advokasi, training, dan pengabdian kepada masyarakat yang pada klimaksnya dapat menciptakan kesadaran masyarakat dan membentuk pola fikir yang lebih aktif-kreatif dalam proses pembangunan.

Dalam konteks inilah kesempatan memperoleh beasiswa untuk menempuh pendidikan tinggi diharapkan akan memberikan pengaruh signifikan bagi peningkatan kualitas masyarakat pendidikan di lingkungan pesantren. Oleh karena itu, Kemenag memberikan perhatian lebih terhadap pengembangan dan pemberdayaan pesantren untuk membangun budaya bangsa yang santun, cinta damai, ramah dan religius. Perhatian tersebut terwujud dalam pemberian beasiswa bagi santri yang memiliki kemampuan akademik, kematangan pribadi, kemampuan penalaran dan potensi untuk dapat mengikuti program pendidikan tinggi.

PBSB sendiri merupakan sebuah program yang cerdas dan taktis dalam rangka meningkatkan kecerdasan anak bangsa lewat pemberdayaan santri. Program ini secara mendasar mengandung beberapa kepedulian yang cukup tinggi terhadap intitusi pesantren. ${ }^{43}$ PBSB didesain sebagai sebuah program afirmatif perluasan akses santri untuk melanjutkan studi melalui suatu program yang terintegrasi mulai dari proses kerjasama, pengelolaan, sistem seleksi khusus bagi santri serta pemberian bantuan pembiayaan yang diperlukan bagi santri yang memenuhi syarat, sampai dengan pembinaan masa studi dan pengabdian setelah lulus.

Tujuan PBSB adalah sebagai bentuk perlindungan sosial bagi santri melalui upaya memperluas akses bagi santri berprestasi. Tidak sedikit santri yang mempunyai kemampuan luar biasa serta kecerdasan yang imajiner, namun mereka terhalang untuk melanjutkan pendidikan ke perguruan tinggi. Kedepan, mereka diharapakan menjadi pelopor bangsa yang siap mengabdi baik kepada

${ }^{43}$ Ibid., 24-45. 
almamaternya (pondok pesantren) maupun negeri ini. Selain itu, PBSB juga bertujuan sebagai bentuk pemberdayaan sosial bagi pesantren melalui upaya meningkatkan kualitas SDM pondok pesantren di bidang sains, teknologi serta sosial kemasyarakatan agar dapat mengoptimalkan peran pembangunan di masa mendatang, melalui penguatan keilmuan di perguruan tinggi.

Banyak pondok pesantren yang mengalami kendala karena minimnya jangkauan akses. Pesantren kekurangan SDM dalam beberapa hal, utamanya saat dihadapkan dengan kemajuan zaman. Misalnya, dalam bidang teknologi informasi, sains, dan lain sebagainya. Dengan adanya program ini, diharapkan akan tumbuh generasi pesantren yang melek teknologi informasi dan tidak ketinggalan zaman. Sebagai upaya penguatan pesantren sebagai lembaga pendidikan, dakwah dan pengembangan masyarakat, PBSB diharapkan dapat menjadi jembatan pembentukan jaringan kerjasama antara dunia pendidikan tinggi dengan pondok pesantren. ${ }^{44}$

Peserta pada tahun pertama berjumlah 33 orang dengan perincian laki-laki 15 orang sedangkan perempuan 18 orang. Sampai pada tahun 2013 atau tahun ke-9 pelaksanaan PBSB, jumlah peserta mencapai 3050 orang yang tersebar di 17 Perguruan Tinggi Negeri (PTN) dan Perguruan Tinggi Swasta (PTS) yang menjadi mitra Kementerian Agama dalam pelaksanaan program ini. Jumlah ini terdiri dari 1547 orang laki-laki dan 1503 orang perempuan. Dari total semua peserta, sebanyak 1526 orang telah menyelesaikan pendidikan mereka, 67 orang tercatat berhenti karena mengundurkan diri, drop out dan meninggal dunia, dan sisanya 1457 orang sedang menempuh pendidikan baik di jenjang sarjana maupun pendidikan profesi.

Dari perincian jumlah peserta PBSB di atas terlihat bahwa jumlah peserta laki-laki dan perempuan masih seimbang atau tidak ada perbedaan signifikan. Bahkan pada perguruan tinggi tertentu jumlah peserta perempuan jauh lebih tinggi daripada jumlah peserta laki-laki. Hal ini, misalnya, yang terjadi di UIN Syarif Hidayatullah di mana jumlah peserta perempuan adalah sebanyak 207 orang sedangkan lakilaki adalah sebanyak 114 orang.

44 Lihat Direktorat Pendidikan Diniyah dan Pondok Pesantren Direktorat Jenderal Pendidikan Islam Kementerian Agama RI, Petunjuk Teknis Bantuan Sosial Beasiswa Santri Berprestasi (Jakarta: Direktorat Pendidikan Diniyah dan Pondok Pesantren Direktorat Jenderal Pendidikan Islam Kementerian Agama RI, 2013), 4-13. 
Jumlah laki-laki dan perempuan yang seimbang dan, dalam beberapa kasus, justru lebih banyak perempuan ini menunjukan adanya persamaan akses dan perlakuan yang sangat berkeadilan gender. Karena masyarakat pesantren yang dipersepsikan publik sebagai masyarakat yang memegang teguh prinsip patrilineal, ternyata partisipasi perempuan dalam pendidikan sama tingginya dengan partisipasi laki-laki, bahkan dalam beberapa hal perempuan lebih unggul. Hal ini diperkuat lagi dengan adanya data santri pondok pesantren dari kategori belajar pendidikan formal yang menjadi sasaran PBSB. Kategori belajar ini terdiri dari madrasah dan sekolah umum dengan jumlah 1.540 .839 dan 395.732 yang jika digabungkan melebihi $50 \%$ jumlah santri keseluruhan. Dalam angka tersebut didapatkan bahwa jumlah siswa perempuan ternyata lebih banyak daripada siswa laki-laki di mana pada kategori belajar madrasah jumlah perempuan mencapai 50,86\% dan pada kategori sekolah umum sebanyak 52,21\%.

Meskipun demikian, penulis menyayangkan bahwa angka-angka tersebut yang ternyata menjadi data acuan bagi pihak pengelola PBSB untuk tidak menyertakan analisis gender dalam dokumen PBSB. Artinya, dalam konteks PBSB tidak diperlukan adanya afirmasi gender. Hal ini karena kesetaraan dan keadilan gender pada masyarakat sasaran telah tercapai. Dengan demikian penulis berpendapat bahwa untuk mengetahui lebih detail terkait perencanaan anggaran PBSB, maka sebaiknya dilakukan analisis anggaran berperspektif gender dengan memperhatikan beberapa hal, diantaranya syarat terlaksananya anggaran responsif gender dan beberapa poin yang harus dilakukan dalam proses perencanaan anggaran responsif gender. Selanjutnya, suatu kebijakan program dapat dikategorikan ke dalam salah satu kategori kebijakan dengan tujuan gender tertentu.

Artikel ini menegaskan bahwa kasus seperti PBSB menunjukkan bahwa hubungan laki-laki dan perempuan bukanlah hubungan yang bertentangan yang dilandasi konflik dikotomis atau struktural fungsionalis, melainkan hubungan yang komplementer, saling melengkapi serta dilandasi kebutuhan kebersamaan guna membangun hubungan yang harmonis. ${ }^{45}$ Ini karena setiap pihak mempunyai

${ }^{45}$ H. L. Moore, Feminisme dan Antropologi (Jakarta: Yayasan Obor Indonesia, 1998), 76. 
kelebihan dan kekurangan serta kekuatan sekaligus kekurangan yang perlu diisi oleh pihak lain dalam bentuk kerjasama yang setara.

Indikator responsif gender atau gender-sensitive indicator mempunyai fungsi yang spesifik untuk menunjukkan perubahan-perubahan yang berkaitan dengan gender dalam pembangunan. Indikator- indikator ini harus mampu menunjukkan perubahan-perubahan status dan peranan perempuan dan laki-laki. Dengan menggunakan indikator responsif gender dalam suatu program akan membantu membuat perencanaan yang lebih efektif, sehingga dapat menciptakan pelayanan yang semakin baik. Indikator responsif gender atau indikator sensitif gender mampu menangkap perubahan yang terkait dengan gender sepanjang waktu tertentu. ${ }^{46}$ Indikator responsif gender ini menyajikan suatu keadaan yang memisahkan antara laki-laki dan perempuan dan menunjukkan hubungan gender yang tidak setara. Indikator responsif gender tidak berarti membuat indikator yang baru, tetapi hanya menjelaskan lebih rinci siapa penerima manfaat program/kegiatan bagi laki-laki maupun perempuan, sehingga para stakeholder bisa menganalisa dan mengevaluasi apabila terjadi ketimpangan.

b. Peran Direktorat Jenderal Pendidikan Islam Kementerian Agama

Direktorat Pendidikan Tinggi Islam, Direktorat Jenderal Pendidikan Islam, Kementerian Agama Republik Indonesia memiliki kepedulian khusus terhadap program Education for All (EFA) dan Millennium Development Goals (MDGs) yang telah menjadi komitmen Pemerintah Indonesia dengan negara-negara lain di dunia. Di antara komitmen yang dihasilkan pada forum dunia tersebut adalah mendorong Keadilan dan Kesetaraan Gender (KKG) dan memberdayakan perempuan dengan cara mengurangi pembedaan dan diskriminasi gender dalam seluruh sektor kehidupan, khususnya di sektor pendidikan.

Oleh karena itu, Bantuan Program Peningkatan Mutu Publikasi Ilmiah dan Hak Kekayaan Intelektual (selanjutnya disingkat BP2MPIHKI) memberikan kuota $30 \%$ bagi para dosen perempuan dan mahasiswi. Bentuk lain komitmen DIKTIS terhadap program ini adalah dengan cara membuatkan kategori khusus untuk karya akademik menggunakan perspektif gender, yakni sebuah pendekatan yang mengedepankan upaya penyeimbangan dan keadilan peran (role)

\footnotetext{
46 Yusuf Supiandi, Kebijakan dan Strategi Pengarusutamaan Gender (Jakarta: Kantor Meneg PP, 2001), 67-70.
} 
dan treatment pada perempuan dan laki-laki tanpa adanya diskriminasi pada salah satu jenis kelamin. ${ }^{47}$

BP2MPI-HKI merupakan kegiatan yang dirancang DIKTIS untuk meningkatkan mutu publikasi ilmiah di lingkungan PTKAI serta didesain untuk mendukung kegiatan pokok program pembangunan pendidikan Islam yang menjadi salah satu tanggung jawab Kementerian Agama, dalam hal ini Direktorat Pendidikan Tinggi Islam, Direktorat Jenderal Pendidikan Islam. Program, khususnya, memberikan akses yang luas bagi dosen dan mahasiswa untuk meningkatkan kapasitas (capacity building) di ranah akademik, khususnya dalam bidang publikasi ilmiah. Hal ini sejalan pula dengan visi dan misi Rencana Strategis (Renstra) Pendidikan Islam, Kementerian Agama 2010-2014, yaitu peningkatan mutu, relevansi, dan daya saing pendidikan Islam. Program ini dikemas dengan cara memberikan dana hibah yang dialokasikan khusus untuk meningkatkan mutu proses, produksi, maupun reproduksi karya ilmiah yang dilakukan oleh dosen, peneliti, dan mahasiswa di lingkungan PTKAI.

Salah satu gambaran umum dari BP2MPI-HKI dalam Program Kluster Penelitian Kompetitif Kolektif Dit. Diktis Tahun 2014, yang fokus kajiannya berdasarkan konsorsium keilmuan yang telah ditetapkan berdasarkan Keputusan Menteri Agama (KMA) No. 36 Tahun 2009 tentang penetapan Pembidangan Ilmu dan Gelar Akademik di Lingkungan Perguruan Tinggi Agama, adalah Penelitian Islam dan Gender (PIG). Program ini memberikan ruang bagi para peneliti yang memiliki ketertarikan untuk mengkaji maupun mengembangkan berbagai permasalahan yang terkait dengan isu-isu Islam dan gender dengan cara menerapkan metode penelitian berperspektif gender, yakni sebuah alat analisis (tool analysis) yang, sebagaimana telah disebutkan di atas, mengedepankan upaya penyeimbangan dan keadilan peran dan perlakuan pada perempuan dan laki-laki tanpa adanya diskriminasi. ${ }^{48}$ Program ini ditujukan untuk meningkatkan intensitas dan kualitas penelitian dan pengembangan pendidikan guna mendukung perumusan kebijakan responsif gender dalam memecahkan permasalahan kendala pembangunan pendidikan.

${ }^{47}$ Lihat Direktorat Jenderal Pendidikan Islam Direktorat Pendidikan Tinggi Islam, Buku Panduan Program Peningkatan Mutu Publikasi Ilmiah, Hak Kekayaan Intelektual (HKI), dan Pangkalan Data Karya Akademik (Jakarta: Direktorat Jenderal Pendidikan Islam Direktorat Pendidikan Tinggi Islam, 2014), 4-15.

${ }^{48}$ Ibid., 25. 
Sasaran dari program ini adalah meningkatkan keterwakilan perempuan dalam rangka peningkatan mutu publikasi ilmiah dan peningkatan proporsi perempuan dalam mengaktualisasikan hak kekayaan intelektual. Masalah keterwakilan perempuan dalam kebijakan memang merupakan di antara persoalan yang paling krusial dalam penentuan apakah kebijakan-kebijakan pemerintahan sudah memperhatikan dimensi gender atau sebaliknya. Masalah keterwakilan ini tidak saja terkait dengan banyaknya perempuan yang ikut serta, namun lebih dari itu keterwakilan ini lebih ditekankan pada upaya pencapaian kebijakan-kebijakan pendidikan Islam tertentu yang mengakomodasi kebutuhan perempuan. Meskipun demikian, jika dilihat dari kuota yang diberikan kepada perempuan, hanya 30\% yang dialokasikan bagi para dosen perempuan dan mahasiswi. Hal ini menunjukkan bahwa perempuan kurang terwakili dalam posisi mendapatkan dan mengaktualisasikan karya akademiknya. Mengingat kualitas kinerja perempuan tidak hanya ditentukan dari jumlah perempuan yang ikut serta dalam program ini, melainkan juga ditentukan oleh kualitas atau mutu mereka, perlu diupayakan adanya keseimbangan antara pemenuhan jumlah dengan kualitas, meskipun untuk affirmative action faktor jumlah merupakan hal yang penting.

Pemberian kategori khusus untuk karya akademik menggunakan perspektif gender, terlepas dari masih minimnya kuota bagi peserta perempuan, membuktikan komitmen DIKTIS dalam hal PUG. Hal ini karena salah satu indikator keberhasilan PUG adalah tersedianya kebutuhan praktis gender, yakni kebutuhan perempuan agar dapat menjalankan peran sosial yang diperankan untuk merespons kebutuhan jangka pendek. ${ }^{49}$ Kebijakan pemerintah yang lebih mengarusutamakan kepentingan perempuan sudah menjadi prioritas dalam kebijakan ini. Peran serta perempuan BP2MPI-HKI menjadi sangat perlu demi mewujudkan keadilan dan kesetaraan gender dalam pendidikan Islam. Hal ini membuktikan bahwa kebijakan ini sudah mencerminkan pengarusutamaan gender.

\section{Penutup}

Kesenjangan gender yang ada di beberapa kebijakan yang dianalisa terjadi di mana posisi perempuan kurang menentukan dalam mempengaruhi arah dan jalannya pendidikan Islam. Strategi PUG dalam bidang pendidikan Islam dapat dilakukan melalui: pertama, kebijakan PUG bidang pendidikan Islam; kedua, manajemen dan

${ }^{49}$ Ibid., 2-34. 
budaya di tingkat satuan pendidikan Islam; ketiga, kurikulum dan pembelajaran pendidikan Islam di dalam kelas; keempat, peran serta masyarakat dan komite madrasah; kelima, sinergi pendidikan Islam dengan pendidikan di bawah naungan Kemendiknas. Program Beasiswa Santri Berprestasi dan Bantuan Program Peningkatan Mutu Publikasi Ilmiah dan Hak Kekayaan Intelektual merupakan di antara kebijakan Kemenag yang dapat diarahkan dengan cara mengintegrasikan perspektif gender ke dalam proses perencanaan, implementasi serta evaluasi kebijakan-kebijakan tersebut, meskipun masih ditemukan beberapa masalah yang belum mencerminkan gender maistreaming.

Mengakhiri tulisan ini, penulis mengutip pendapat Anderson (1983) yang menegaskan bahwa kebijakan sensitif gender adalah kebijakan yang mencerminkan kepentingan laki-laki dan perempuan secara setara. Di dalam lingkup publik, sumber daya dialokasikan melalui kebijakan publik. Alokasi sumber daya dalam lingkup publikpun terbukti tidak memberikan kesempatan yang sama berdasarkan gender. Pilihan-pilihan dan partisipasi perempuan dalam proses kebijakan yang sangat terbatas, akibat proses sosialisasi yang selama ini ada, menyebabkan perempuan harus melalui banyak rintangan ketika akan memasuki area kebijakan. ${ }^{50}$ Mengacu pada statement ini penulis ingin menegaskan bahwa berbagai program kebijakan dari pusat, termasuk Diktis Kemenag, sebaiknya ditelaah secara simultan apakah sudah sesuai dengan kenyataan di dalam masyarakat. Norma yang selama ini sering digunakan sebagai acuan perlu ditinjau kembali, agar kebijakan yang yang diambil tepat sasaran, meskipun-semua pihak harus menyadari dengan legawa bahwapenyeragaman kebijakan tidak dapat selalu diterapkan karena peran gender, bagaimanapun, berbeda baik antartempat, waktu dan kelas sosial ekonomi masyarakat.

\section{Daftar Rujukan}

Anderson, Margareth. Thinking about Women: Sociological and Feminist Perspective. New York: Mac Millan, 1983.

Arivia, Gadis. Feminisme: Sebuah Kata Hati. Jakarta: Penerbit Buku Kompas, 2006.

Ch., Mufidah. "Hasil Evaluasi Implementasi PUG Bidang Pendidikan Islam," Monev Pilot Project Pengarusutamaan Gender Bidang

\footnotetext{
${ }^{50}$ Margareth Anderson, Thinking about Women: Sociological and Feminist Perspective (New York: Mac Millan, 1983), 23.
} 
Pendidikan Islam di Yogyakarta, 5-6 Maret 2010. Dokumen Tidak Dipublikasikan--Program Kemitraan Kementerian Agama dengan MCPM-AIBEP.

Daly, M. "Gender Mainstreaming in Theory and Practice", Social Politics: International Studies in Gender, State and Society, Vol. 12, No. 3, 2005.

Dewi, Sinta R. "Pengarusutamaan Gender", Jurnal Perempuan, Edisi ke50. Jakarta: Yayasan Jurnal Perempuan, 2006.

Direktorat Jenderal Pendidikan Islam Direktorat Pendidikan Tinggi Islam, Buku Panduan Program Peningkatan Mutu Publikasi Ilmiah, Hak Kekayaan Intelektual (HKI), dan Pangkalan Data Karya Akademik. Jakarta: Direktorat Jenderal Pendidikan Islam Direktorat Pendidikan Tinggi Islam, 2014.

Direktorat Pendidikan Diniyah dan Pondok Pesantren Direktorat Jenderal Pendidikan Islam Kementerian Agama RI, Petunjuk Teknis Bantuan Sosial Beasiswa Santri Berprestasi. Jakarta: Direktorat Pendidikan Diniyah dan Pondok Pesantren Direktorat Jenderal Pendidikan Islam Kementerian Agama RI, 2013.

Fakih, Mansour. Analisis Gender dan Transformasi Sosial. Yogyakarta: Pustaka Pelajar, 2004.

Handayani. Konsep dan Teknik Penelitian Gender. Malang: UMM Press, 2002.

Ismail, Nurjannah. Perempuan dalam Pasungan: Bias Laki-laki dalam Penafsiran. Yogyakarta: LKIS, 2003.

Kementerian Perencanaan Pembangunan Nasional/Badan

Perencanaan Pembangunan Nasional (BAPPENAS), Evaluasi Parub Waktu RPJMN 2010-2014. Jakarta: BAPPENAS, 2013.

Khan, Qamaruddin. Status of Women in Islam. New Delhi: Sterling Publishers Put. Ltd., 1990.

Moore, H. L. Feminisme dan Antropologi. Jakarta: Yayasan Obor Indonesia, 1998.

Mustaqim, Abdul. "Pemikiran Riffat Hassan tentang Feminisme", Jurnal Studi Islam Profetika, Vol. 3, No. 1, Januari, 2001.

Nation, The United. The Millennium Development Goals Report 2013. New York: The United Nation.

Nugroho, R. D. Public Policy: Teori Kebijakan, Analisis Kebijakan, Proses Kebijakan, Perumusan, Implementasi, Evaluasi, Revisi, Risk Management dalam Kebijakan Publik. Jakarta: PT Elex Media Komputindo, 2012. 
Nurhaeni, Ismi Dwi Astuti. Reformasi Kebijakan Pendidikan Menuju Kesetaraan dan Keadilan Gender. Surakarta: LPP-UNS Press, 2009.

Penyusun, Tim. Grand Desain Program Beasiswa Santri Berprestasi 20052014: Mengubah Takdir Bangsa 2025. Jakarta: Direktorat Pendidikan Diniyah dan Pondok Pesantren Direktorat Jenderal Pendidikan Islam Kementerian Agama RI, t.th.

Penyusun, Tim. Membangun Relasi Setara antara Perempuan dan Laki-laki melalui Pendidikan Islam. Jakarta: Direktorat Jenderal Pendidikan Kementerian Agama-Australia Indonesia Partnership, 2010.

Penyusun, Tim. Panduan Pelaksanaan Inpres Nomor 9 Tahun 2000 tentang Pengarusutamaan Gender dalam Pembangunan Nasional. Jakarta: Kementerian Pemberdayaan Perempuan, 2002.

Penyusun, Tim. Panduan Pengarusutamaan Gender Bidang Pendidikan: Buku II Kebijakan Pengarusutamaan Gender Bidang Pendidikan. Malang: Indonesia-Australia Partnership in Basic Education, 2007. Peraturan Menteri Negara Pemberdayaan Perempuan dan Perlindungan Anak Republik Indonesia Nomor 12 Tahun 2010 tentang Pedoman Perencanaan dan Penganggaran pada Pendidikkan Islam yang Responsif Gender.

Quthb, Sayyid. Keadilan Sosial dalam Islam. Bandung: Penerbit Pustaka, 1984.

Satyawan, I. "Gender Mainstreaming in Education: An Indonesian Experience", dalam S. Tarjana (ed.), Pergeseran Paradigma Pembangunan Pemberdayaan Perempuan Menuju Pengarusutamaan Gender. Solo: Cakra Books, 2007.

Subhan, Zaitunah. Menggagas Pemberdayaan Fiqh Perempuan. Jakarta: ElKahfi, 2008.

----. Tafsir Kebencian: Studi Bias Gender dalam Tafsir al-Qur'an. Yogyakarta: LKIS, 1999.

Supiandi, Yusuf. Kebijakan dan Strategi Pengarusutamaan Gender. Jakarta: Kantor Meneg PP, 2001.

Suryadi, Ace dan Idris, Ecep. Kesetaraan Gender dalam Bidang Pendidikan. Bandung: Genesindo, 2004.

Taylor, M. "Gender and Development", dalam Banúlacht: Women in Ireland in Global Solidarity, dalam http://www.banulacht.ie /docs/Taylor_Gender_and_Development.doc (Diakses 12 Maret 2015).

Umar, Nasaruddin. Argumen Kesetaraan Gender Perspektif Al-Quran. Jakarta: Paramadina, 1999. 
Ursula, King. "Introduction: Gender and the Study of Religion, dalam "Religion and Gender. USA: Blackwell, 1995.

Wahid, M. Hidayat Nur. "Kajian atas Kajian Dr. Fatima Mernissi tentang Hadis Misogini”, dalam Membincang Feminisme: Diskursus Gender Persfektif Islam, ed. Mansour Fakih. Surabaya: Risalah Gusti, 1996. 